\title{
Free ports: towards a network of trade gateways
}

Alexandre Lavissière ${ }^{1^{*}}$ (D) and Jean-Paul Rodrigue ${ }^{2}$

\author{
* Correspondence: alavissiere@em- \\ normandie.fr \\ ${ }^{1}$ Métis Lab, École de Management \\ de Normandie, Le Havre, France \\ Full list of author information is \\ available at the end of the article
}

\begin{abstract}
Free ports are a form of territorial exceptionalism that has existed for centuries and become an important paradigm of globalization. In the contemporary setting, they act as transportation, logistics and trade platforms, using their territorial exceptionalism as a competitive advantage. Free ports such as Hong Kong, Singapore and Dubai are among the world's leading commercial gateways, offering a form of leverage to transactions, transportation and the transformation of material goods. The historical evolution of free ports underlines a growing complexification and specialization that has led to a multitude of models, each fitting a specific regulatory and operational framework.

This paper aims rationalizing the complexity of free ports. It is based on a wide array of empirical observations and an analysis of structure, function and evolution of free ports. Collected free ports data enabled the identification of three constitutive factors of evolution: an external factor (the jurisdiction), an internal factor (the services provided) and a linking factor (the orientation of flows). Based on these three factors a model of free ports was designed with a typology of thirteen types of free ports, an explanation of their evolution, and their future prospects.
\end{abstract}

Keywords: Free port, Foreign trade zone, Gateway, Port, Globalization, Logistics network

\section{Introduction}

Free ports are a formally defined area, often encompassing a whole city, with enabling custom regulations and usually permitting foreign investment and ownership. Although free ports have existed for centuries, they have seen during the last few decades a growing importance as transportation, logistics and trade platforms with their number and locations expanding (Bost, 2011). They are thus not limited to specific geographical areas or levels of development, but are widespread forms of transnationalism. While in 2012, Madagascar, one of the world's poorest countries, was launching a new free port, in the United States, about 370,000 people were employed in more than 3200 firms operating in 276 free zones (Congress of the United States Foreign Trade Zone Board, 2013), which accounted for about half of American imports (Tiefenbrun, 2012).

The development of free ports is an example of how inland logistics shapes maritime transport through the growth of international trade and the strategies of freight forwarders to handle, distribute and process cargo that has an international origin or

(c) The Author(s). 2017 Open Access This article is distributed under the terms of the Creative Commons Attribution 4.0 International License (http://creativecommons.org/licenses/by/4.0/), which permits unrestricted use, distribution, and reproduction in any medium, provided you give appropriate credit to the original author(s) and the source, provide a link to the Creative Commons license, and indicate if changes were made. 
destination (Rodrigue and Notteboom, 2009). Understanding free ports as a specific structural and functional node of international transport requires further evidence about the interactions between dry ports (inland terminals), transportation corridors and port competitiveness, particularly as it relates to trade (Slack, 1999; Roso et al., 2009; Wilmsmeier et al., 2011). Trade facilitation is mostly an issue addressed at the macroeconomic level - see for instance Farole (2011) Barbier and Véron (1991) and Arvis et al. (2007) -, but the spatial forms such policies take at major gateways and their hinterland remains to be more closely investigated. The free port represents a relevant unit of analysis where trade facilitation is shaping the structure of flows and particularly how the supporting elements, including port terminals, intermodal yards and logistics zones are established and integrated.

\section{Literature review}

Free ports have been elements of the international trade system for centuries (Aftalion, 1901; Thoman, 1956; Bost, 2011; Lafargue, 2008; Farole, 2011) and have been subject to several changes in their role, nature and function. In the second half of the twentieth century the concept further evolved as international trade became increasingly liberalized. What was previously called a free port diverged into several concepts of free zones such as free trade zones (FTZ), foreign trade zones (FoTZ), export processing zones (EPZ), and special economic zones (SEZ). The World Bank (2008) provided one of the first attempts to define the variety of free zones that have emerged in recent decades:

- Free trade zones (FTZ) are considered to be enclosed duty-free areas for the purpose of providing warehousing and distribution facilities supporting trade, particularly re-exports. They are commonly near a point of entry, such as a port, an airport or a land border.

- Export processing zones (EPZ) are offering incentives for manufacturing and related activities with a particular focus on exports, although several such zones allow nonexporting activities.

- Free ports are considered to be the broader term of a free zone as they include a rather large area and can cover a wide range of activities and incentives to promote economic development and trade.

- Special economic zones (SEZ) are a free port paradigm that has been particularly applied to the Chinese context as a tool to promote foreign direct investments in well defined areas (Wang, 2013).

The literature thus underlines a functional and modal specialization of free ports. Free ports are developed adjacent to a wide range of transport nodes, including sea ports, air ports, river ports, and dry ports (railyards). The relevance of free ports is underlined by the increasing number of countries developing them and the amount of Foreign Direct Investments (FDI) invested in these zones around the world (Farole, 2011).

The literature on free ports is mostly focusing on their conditions of success and their impacts. Economic conditions that may favor emergence of free ports have been largely investigated (Farole, 2011; Haywood, 2000; Kusago and Tzannatos, 1998; Rhee et al., 1990) as well as their impacts (Miyagiwa, 1986; Baissac, 1996; Schwob and Lorot, 1987; Madani, 1999; Schrank, 2001). In the same way, legal (Blanc, 1996; Trampus, 
1999), geographical (Bost, 2011; Yang, 2009) and social (Susman and Schneider, 2008) conditions brings light to favorable frameworks that help the development of free ports. The impacts of free ports, in their legal (Fedi and Lavissière, 2014; ILO/UNCTC, 1988), geographical (Bost, 2007), social (Barbier and Véron, 1991) and financial (Lu and Yang, 2007) aspects, have also been investigated. Major impacts listed are improvements in the connectivity of the port area, as well as attracting Foreign Direct Investments, logistics actors capitalizing on expanded trade flows and the dissemination of innovation and best practices among the workforce.

There are also geographical agglomeration effects with the creation of logistic platforms around industrial and logistic clusters, many of which are free zones (Sheffi, 2012). As global trade expanded, the logistical function of free ports became more pronounced with the setting of intermodal facilities, distribution centers as well as related service activities, particularly around major port facilities (Rodrigue and Notteboom, 2009).

However, there is limited literature dedicated to free ports and no widely accepted definition of the phenomenon. Furthermore, a divergence in the usage of the term in light of function (e.g. technology parks) and even marketing is observed. The World Bank (2008) provided a general typology of free zones, but little is mentioned about their evolution and mutation considering shifting economic and commercial contexts. Finally, outside general definitions, there is no typology of the different types of free ports. There is therefore the need for the development of a model of free ports that would provide a better understanding of the phenomenon from a geographical, functional and evolutionary perspective.

\section{Methodology}

Various authors emphasized the benefits of case studies when gathering empirical evidence about a topic (Abbott, 1992; Easton, 1995; Eisenhardt, 1989). Case studies embed an object in context (Harrison et al. 2010), allow depth, detail, and richness of data, are longitudinal by default (Easton, 1998) and are process-oriented. In the present study, the free port phenomenon is considered as a single case with various occurrences in time, space and forms.

In terms of data collection, the review of free ports was supported by a mix of primary and secondary data. The building of the case study (Yin, 1994) was based on multiple sources of evidences (documents, archival records, interviews, direct observations and participant observation). Documents have been collected in international institutions reports, available specialized consultant reports, governments and free ports websites, codes of laws, archival records (e.g. Thoman, 1956; Aftalion, 1901) and press releases.

Interviews have been conducted from 2007 to 2015 as part of ongoing research projects on free ports. More than 50 interviews have been conducted in 17 countries on 4 continents (Brazil, Cameroon, China, France, French Guyana, Germany, Madagascar, Malaysia, Mauritius, Morocco, Panama, Singapore, Spain, Tunisia, UAE, UK, and USA.) Interviewees were government agents, free zone administrators, customs officers, investors, logisticians, manufacturers and operators of free ports. In most of the countries direct observation of the free ports was possible and brought valuable data. Finally, in few free ports (Mauritius Free Port, Ehoala Park, Tangier-Med, Manaus Suframa, Radès, and Kribi) participant observations was possible due to the involvement in 
audits, creation, restructuration or development of free ports, during consulting missions. The authors thus bring a wide array of empirical observations with their academic and professional interactions with actors involved in free ports.

The consolidation of data and its analysis was complex and required a methodological tool being able to deal with this complexity. Systemic triangulation (Durand and Nuñez, 2002) is such a tool dealing with the evolution of a phenomenon and its interaction with its environment. The systemic triangulation is composed of a functional aspect, a structural aspect and a historical aspect. In order to systematically implement the structural component of triangulation, there is a systematic division of data, which is based on certain criteria (purpose, history, level of organization, structure) (Donnadieu and Karsky, 2002). Free ports data was investigated applying this method in order to build a model of free ports with a typology, an explanation of the mutations of free ports in time and their future prospects.

\section{Case study}

\section{Free ports as logistics networks}

Understanding what the term free port covers is the first step to approach the structure of free ports. The Atlas of the Free Zones in the World (Bost, 2010), compiled more than forty-five different names that have been used related to the concept of free zones. According to the author, these terms are often used interchangeably, and sometimes they are simply marketing terms from the promoters of a zone. Therefore, there is confusion about both definitions and concepts. From this taxonomy, it is considered that free zone is a concept that can be divided into two categories: export processing zones that are manufacturing-oriented free zones and free trade zones that are trade-oriented free zones. The World Bank (2008; Farole, 2011) has the same dual approach by using the term special economic zone while referring to a free zone. This term makes sense if the status of such zones is considered although it creates confusion because there is a specific Chinese model of free zones named Special Economic Zones and this model covers only a part of the concept. Free port, however, is the long-standing terminology of such zones and refers to the logistic function of the concept (Lavissière et al., 2014). It is argued that the term free port is a transversal concept of free zones and a free port can either be an export processing zone or a free trade zone. It is therefore the term that has been retained.

In addition, it is crucial to avoid confusion on what a free port is. Free ports are different from free trade zones, special economic zones and export processing zones, because they are logistic oriented free zones whatever their free zone status or name. Free ports are also different from the concepts of sea ports and port terminal; they are special logistics zones next to ports. The definition of free port from Lavissière et al. (2014) was retained. It states that 'A free port is an international logistic interface that is free from border frictions and designed to bring more value in the global supply chains of its operators. This definition states that the free port is not the port, but the logistics facility 'often next to a sea port but also next to or within an airport, a river port, or a dry port.'

In terms of organization, Lafargue (2008) points an evolution in the governance of free ports from publicly managed entities to landlord free zones, while Bost (2011) underlines the ongoing specialization of free zones to cater to specific supply chains. Free 
ports are evolving with the range of added value activities they provide from labor intensive to high value added products (Barbier and Véron, 1991). In the same manner, services offered by free ports are evolving to include ancillary services such as finance and insurance (Tiefenbrun, 2012). These organizational and marketing drivers represent the internal factors of the evolution of free ports.

Industrial scope and customs extraterritoriality constitute the external factors of evolution of free ports. Industrial scope is represented by the typology of the zones; Free trade zones are mainly importing to reexport, while export processing zones are meant to transform products and then reexport them (Farole, 2011; Bost, 2007). Customs extraterritoriality not only brings a reduction of tariffs, but also of border frictions (Lavissière, 2014) as it facilitates gateway access to the hinterland (Yang, 2009) and confers a juridical status dedicated to international trade (Trampus, 1999; Fedi and Lavissière, 2014).

\section{The historical evolution of free ports}

Several studies demonstrate that Free ports, as a trade concept, started with the Phoenicians around the ninth Century BC (Thoman, 1956) and probably in ancient China around the same period, developed in Piraeus and Delos during Antiquity (Hasebroek, 1928; Frank, 1927), then morphed in Middle Age Europe (Schwob and Lorot, 1987) with free fairs cities (Freetowns, Friburgs, Villafrancas, Villefranches, etc.) (LombardJourdan, 1987), and developed in the Hanseatic League ports as well as Mediterranean ports in the Mercantile Area (Abu-Lughod, 1991).

The modern era is characterized by the globalization, through the exchange of goods, capital, information and even the movement of large groups of people worldwide. This acceleration is also visible in terms of free ports. While before the 1920's, only developed countries had free zone regulations, from this point in time, free zones, with multiple forms and names expanded to include the whole world.

More recently, container ports created logistic value and the provision of bounded areas for transiting flows was part of this value proposition. Free ports are a common component of the world's most important gateways. For instance, the Mediterranean basin and Northern Europe (Fig. 1) underline the concentration of a large number of free ports. These ports are also classified according to if they are predominantly gateways (most of the activity is intermodal; hinterland related) or hubs (most of the activity is transmodal; foreland related). Every major transshipment hub is a free port except Antwerp. Nationwide, Albania, Belgium, France, Norway and Sweden do not have free ports. Concerning France, the reason for this lack is political since historically France considered free zones as commercial privileges (Schwob and Lorot, 1987). Albania is still a centrally planned economy in which free zones are not compatible with the domestic regime (Bost, 2010). Belgium is a transit country and freight forwarders mostly use the inward processing relief system. ${ }^{1}$ Under this regime, duties are paid if imported goods are processed for re-export or released to be distributed within the European Union. Norway and Sweden never had free ports (Kugler, 1922; Thoman, 1956) and the fact they historically played a limited trade intermediacy function provided limited incentives to change this status (Bost, 2010). Thus, when free ports are not present, it is either because there is limited need for them because of the existing trade structure or because there are existing mechanisms providing a palliative. 


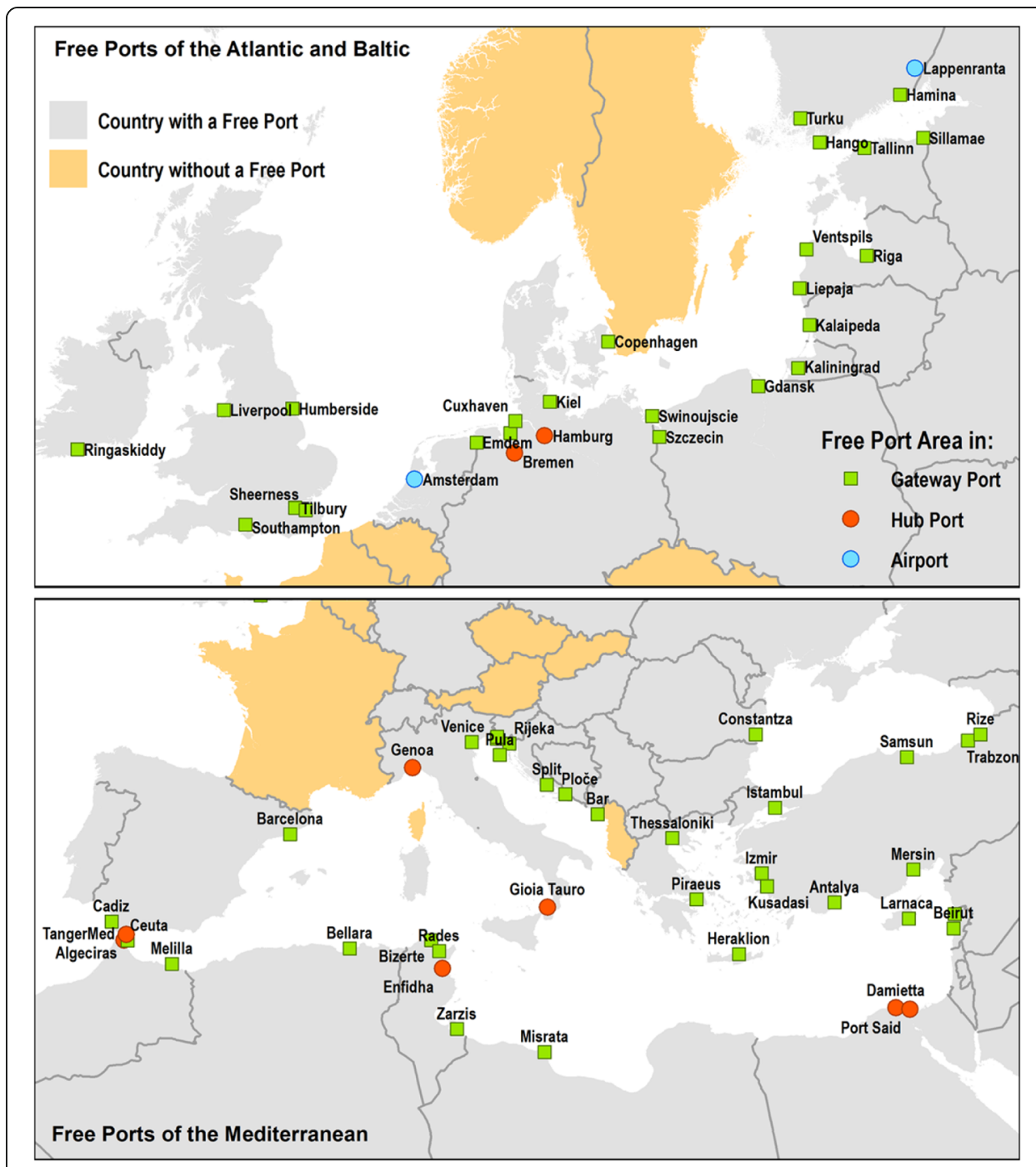

Fig. 1 Free Ports of the Atlantic, Baltic and Mediterranean. (source: Source: constructed by the authors)

The concept of free port has experienced in the twentieth century both a functional and a geographical diffusion. Particularly, since the end of the Second World War the locational concept of free port has been expanded from its maritime ports setting to include river free ports (for example Manaus, Brazil), lake ports (for example, Chicago, USA), airports (for instance, Shannon, Ireland) and inland ports (for instance, Zona Franca Florida Sur, Uruguay). Shannon's free zone was created in 1958, next to the Shannon Airport, which was used as a supply base for American aircrafts since the airport lies at one of westernmost point of Europe. Shannon rapidly developed a suite of logistic services including packaging and customization, and later on, manufacturing, but the focus remains on services (Barbier and Véron, 1991). With the emergence of the European Union, the advantages that the free zone offered receded, underlining that the evolution of the regulatory and commercial environment are closely linked with the relevance a free port has in its regional context.

Free ports also became widely adopted across geographies (Fig. 2). Prior to 1920, the location of free trade zones was predominately in six developed countries, totaling less 


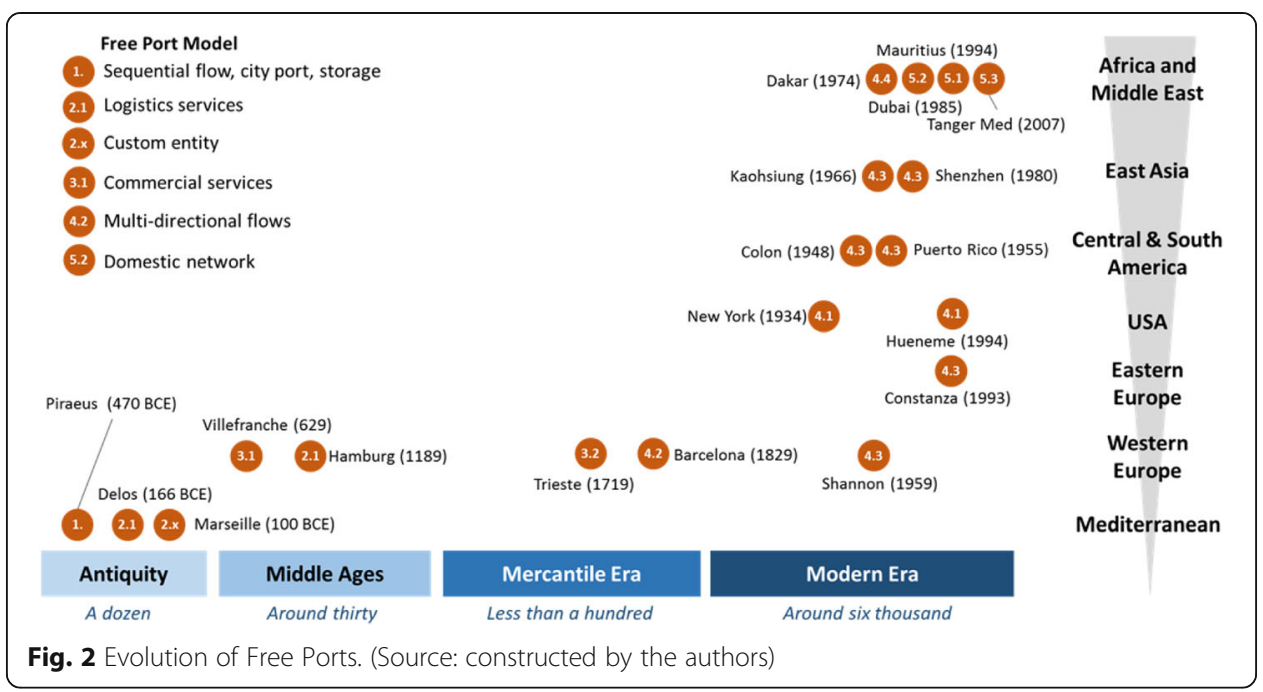

than 20 zones. By 2010, over 1735 Free Zones were located in 133 countries (Bost, 2010), of which 356 were free ports (Lavissière, 2014). In addition, the range of service expanded substantially to include distribution, manufacturing and commercial real estate.

From a historical point of view there is, therefore, a parallel evolution between the globalization of trade, the development of customs entities (cities, states, and customs unions) and free ports. This evolution went from the protection of existing trade, the attraction of additional trade, to the connection to trade networks and, finally, to the competition between trade networks. Free ports have become an integration tool to global trade such as for East and Southeast Asian export-oriented economies. Further, free ports such as Dubai were established to try to capture the opportunities of being intermediary locations along long distance shipping routes.

\section{Actors and the function of free ports}

In the United States the process began early in twentieth century with the creation of Foreign Trade Zones (FTZ) following the Smoot-Hawley Tariff Act of 1930 and accelerated after World War II (Tiefenbrun, 2012). In the 1950s, FTZ were allowed to have manufacturing activities. The success of FTZ was mitigated by the protected status of American industries that were under customs barriers with a large enough domestic market. However, in the 1970s trade liberalization (the outcome of a succession of GATT rounds) enabled a greater access to the American market by foreign firms. American manufacturers started to look for new ways to take advantages of the cost arbitrage offered by international markets; foreign trade zones were such a tool and grew rapidly to include all the main maritime, air and land ports of entry. There were around 50 foreign trade zones in 1979, around 100 in 1984, more than 200 in 1993 and more than 230 in 2015.

Free ports have also been a development tool for Asian economies. Bost (2010) underlined that a parallel exists between export-oriented industrialization and the use of free ports. For example, Taiwan and South Korea started export-oriented industrialization by setting their first free zones in Kaohsiung and Masan in the 1960s (Amirahmadi and Weiping, 1995). When other Asian countries such as Malaysia, Sri 
Lanka, Thailand, and the Philippines started to consider export-oriented development, they also implemented free zones. The recent setting of free ports in Madagascar, Morocco and Tunisia underlines a similar strategy (Lavissière, 2014).

Rather than simply opening to globalization, free zone programs have also enabled countries to open to free market reforms in a controlled manner by deciding upon its locations and conditions. Bost (2011) underlined that China partially and selectively opened its economy to capitalism through free zones; Special Economic Zones became islands of experimental capitalism, and these zones were initially separate from the domestic economy. ${ }^{2}$ While free zones have been territories opened to foreign products in the past, in China they also supported an emerging global division of production. The case of Shenzhen is illustrative. From its opening in 1980, with the Pearl River Delta, it became one of the world's most extensive manufacturing complex and recently a cluster of high tech innovation.

In the same way, former Soviet bloc countries choose to open their economy to capitalism through the implementation of free zones along the Adriatic, the Black and the Baltic Seas (see Fig. 1). Iran is also currently following a similar strategy as a way to mitigate economic sanctions imposed in particular by the European Union and the United States. In this context, free ports are tools not only to influence freight flows, but to reform an economy in a controlled fashion (Bost, 2010). In some cases, the free port can become the main driver of national economic development, as the case of Dubai illustrates by combining port, airport and real estate development and creating a free port in a relatively closed regional context.

At the microeconomic level, few studies show the advantages for users of the free port. This core function is briefly mentioned by Tiefenbrun (2012) in a list of advantages for users of American foreign trade zones. These advantages are mostly commercial, fiscal and financial. Lafargue (2008) explains there are different advantages and functions of the free port for the four categories of actors mentioned: State, Regulator, Developer and Users. Lavissière et al. (2014) explained that the main function of free ports is to reduce border frictions for international supply chains through fiscal, logistical and cultural advantages. Barbier and Véron (1991) incorporated several of these elements in order to show an evolution in time of the function of free ports. The more developed the free port, the wider services are.

\section{Toward a model of free ports}

\section{Factors in the evolution of free ports}

The historical, structural and functional analyses of free ports mentioned above, made possible the identification of major factors describing the wide range of existing free ports.

The first factor emerging from the case study is customs extraterritoriality. This is the core characteristics of free ports and one that is present in every free port studied, although it evolved in time. Customs extraterritoriality is a juridical factor making the link between the structure of the free port and its environment. This factor alone, however, is not sufficient to explain the evolution of free ports and their wide variety. Moreover, the reduction of customs barriers with the GATT and then the WTO, while free ports were growing in number proves that the sole customs extraterritoriality is not fully explaining the issue. 
The evolution of free ports along with globalization of trade is another major factor. The adaptation of free ports to wider ranges of services in order to cope with evolutions of supply chains is another factor. Logistics functions of free ports have become more complex and complete to cope with global supply chains and incorporate free ports in the international trade system. Adding this factor explains a large part of the evolution of free ports, but it does not cover the different types of free ports and especially the free trade zone system that is predominantly developed in OECD countries and the Export Processing Zone system that is only present in developing countries.

The functional distinction between trade orientation free ports (FTZ) and industrial oriented free zones (EPZ) is not the main point since free ports represent the logistics orientation of both types of free zones. What matters in the distinction are the involved trade flows. Developing countries concentrate on EPZ in order to attract flows that were not going through their territory; while developed countries concentrate on FTZ in order to attract existing flows upstream of the supply chain without changing the orientation of these flows. The former system attracts trade flows, transforms them and re-export them; the latter attracts, transforms and imports or retain, transforms and exports.

The combination of these three factors help understand the stages in the evolution of free ports as well as their transition from one stage to another (Fig. 3). These factors are summarized as the jurisdictional environment (external factor), the functional aspect (internal factor) and the orientation of trade flows (factor that links the other two).

Factor 1 - External - Jurisdictional environment

The evolution of the external factor follows three stages: a city state or depot stage, in which the free port does not belong to any customs entity; then a customs entity stage in which the free ports links an external customs area and a domestic customs area; and last a network of duty free zones connecting free ports inside or outside the same customs area.

The external factor involves the political and administrative context of the free port. Free ports exist because there are frictions to international trade created by boundaries between different regulatory regimes (Lavissière, 2014) and as such free ports provide a form of extraterritoriality as well as logistical services to mitigate these frictions.

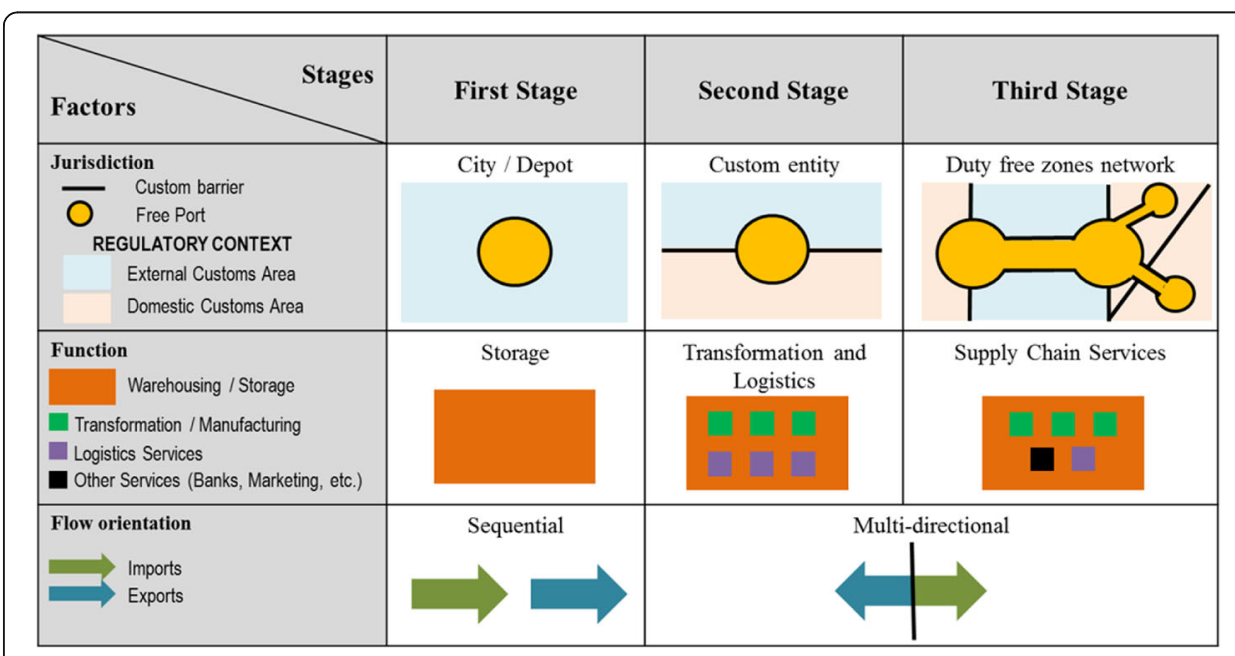

Fig. 3 Factors and Stages of Free Port Development. (Source: constructed by the authors) 
Therefore, the evolution of the institutions that generate administrative frictions and customs barriers has had an influence on the evolution of free ports. Early free ports were connecting two customs areas outside of their own. Then, free ports developed within nation states. This changed the trade function because free ports became a link between domestic legal provisions and the outside. French free ports in the mercantilist era, and later on Spanish free ports and American Foreign Trade Zones are examples of entities set to mitigate the complexity of domestic customs and global markets.

Today, few free ports remain at the level of a city state, but there are notable exceptions such as Singapore, Hong Kong, Malta and Dubai. Still, they belong to larger economic entities having a common customs regulatory regime. Nowadays, there are free ports connecting to a network of free zones. These free ports are incorporating different types of free zones such as industry and services into a 'free zone area'. Mauritius, for instance, linked the free zones of its port and airport to industrial zones producing textile and then developed an IT dedicated free zone (Lavissière, 2014). All these zones are linked commercially but also physically within customs corridors (where flows are permitted on the domestic system as long as they go from one element of the free zone to another). Tanger-Med has a similar development strategy with its port, a planned airport, an automotive free zone, a logistics free port, an industrial free zone and an offshore banking free zone. This model illustrates a regionalization of free ports by permitting a specialization of the free port functions within the free port itself as well as through satellite facilities. Thus, the regulatory framework of free ports corresponds to infrastructural developments of transport terminals in regard to their hinterland. Tanger-Med and Barcelona Free Zone also signed an agreement on promotion, exchange of best practices and trade facilitation that creates a customs free corridor between the two entities. In the United States, free zones are technically networked since it is possible to move goods from one zone to another without disbursing custom duties. Still, this status is in its infancy at the transnational level and it remains to be seen the scale and extent free ports will create effective trade networks.

\section{Factor 2 - Internal - Free port function and services provided}

The internal factor relates to the function of the free port and the services it provides. Initially free ports were only a transloading infrastructure and many eventually developed as added value platforms. Hanseatic ports of the twelfth century brought transformation activities to the storage function. In time, free ports kept adding services of increasing complexity; from manufacturing to supply chain services and offshore banking facilities. Furthermore, in the twenty-first century a specialization emerged where the free port specializes in logistics and supply chain services while other adjacent zones are specializing in banking, IT services, or manufacturing. The free port focuses on its core competencies and becomes part of a local network of specialized free zones. From that perspective, three stages in the evolution and complexification of this internal factors can be identified; storage, transformation and logistics and supply chain services.

\section{Factor 3 - Linking factor - Orientation of trade flows}

Trade flows underlines the nature and evolution of the trade supported by the free port. Initially, a free port was at the center of a regional trade system because transportation was only allowing trade over short distances, while long distance trade was marginal at best. This was particularly the case during the Middle Ages. During the 
mercantilism era, the scale and scope of trade routes expanded and many free ports developed as colonial outposts (Bost, 2010). While the trade routes were longer and more extensive, the free port remained mostly a point of transshipment between areas where goods were produced and colonial consumption markets. Globalization changed the organization of production and, therefore, the orientation of trade flows (Rodrigue, 2017). The spatial division of production and the growing reliance on logistics transformed the function of many free ports from single transloading points along sequential trade flows towards nodes within global value chains (Lavissière et al., 2016).

The orientation of flows went from a sequential process where what was being imported became an export to a multidirectional structure involving differences in the composition of imports and exports. The function of free ports evolved from simple storage and transshipment to complex logistics services, including in several free ports a specialization with distinct free areas (logistics free zone, manufacturing free zone, services free zone).

\section{Free port models}

The three factors presented above are used to develop eighteen possible free port models (Fig. 4). Starting from a model in which the three factors are at the first stage (city jurisdiction; storage function and sequential flow orientation), complexity is added by changing one of the factors at each sequence. The combination of three factors with three (Factor1), three (Factor2) and two (Factor3) stages provides eighteen possible models. These eighteen models cover the whole spectrum of possible models described by the three factors and where the outcome is an evolutionary framework with a path dependency mechanism (i.e. it is not possible to go from stage one to stage three, as shown in the historical aspects of the case study). For each model, empirical evidence provided a representative free port. These eighteen models start from a quite simple

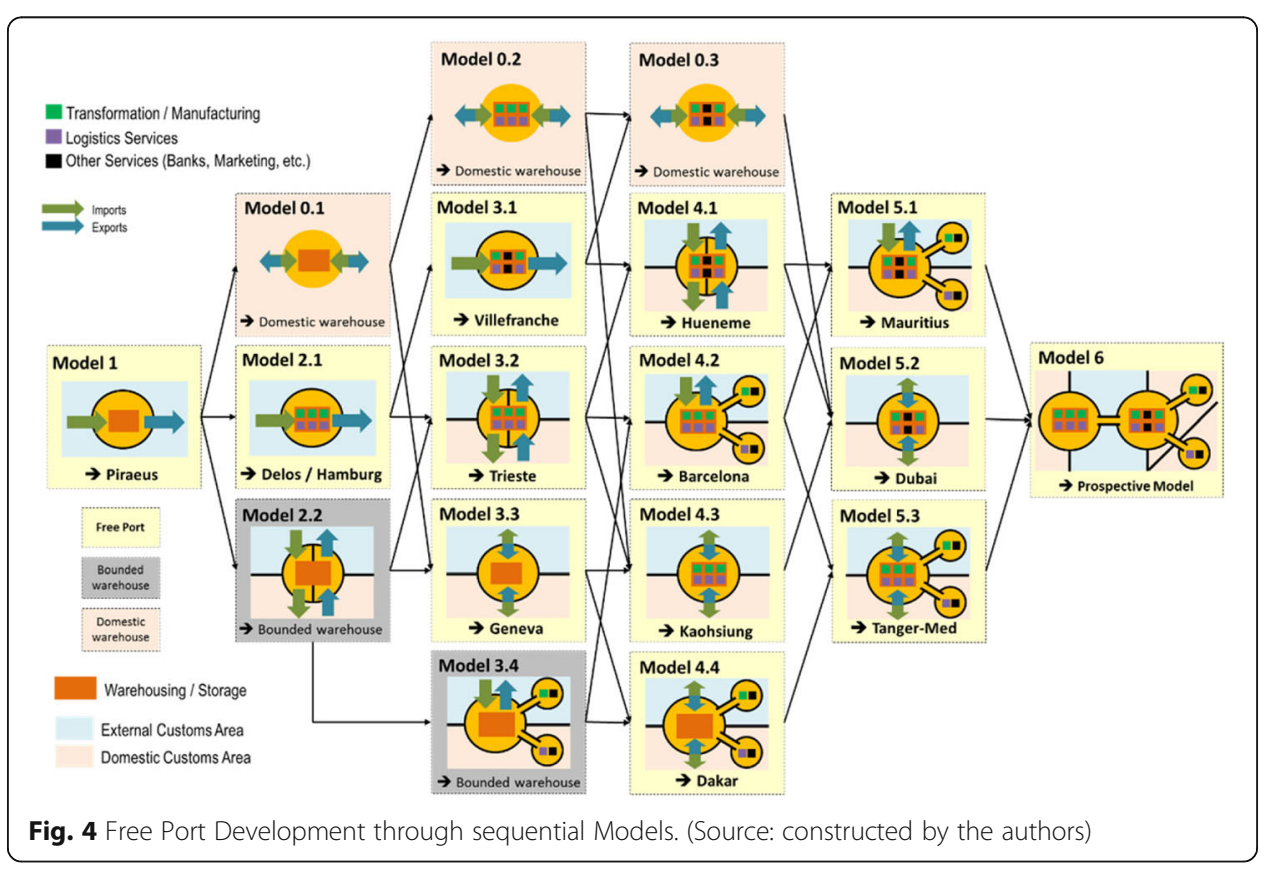


free port model of the Antiquity (Piraeus) to end with three complex contemporary examples of multi-zonal free ports (Mauritius, Dubaï and Tanger-Med) and an even more complex prospective model of a network of free ports.

From the eighteen possible models, three can be discarded because they are not free ports but domestic warehouses with a multi-directional orientation of flows, but with no customs entity (Models $0.1,0.2$ and 0.3 ). This can only exist when the port is located inside a customs area and therefore it is not offering any form of extraterritoriality.

Two additional models represent first stage function with only storage while the jurisdiction factor gets more complex, either at the stage of customs entity or duty free zones network (Models 2.2 and 3.4). These two models represent bounded warehouses and because bounded warehouses are storage warehouses under extraterritoriality that are not offering any transformation, logistics of supply chain services.

There are therefore thirteen effective free port models, with each model taking the name of the innovative or representative free port. The simplest (and earliest) is the Piraeus model where the three factors are at their first stages. From that point, there is a complexification converging towards a prospective model in which all three factors are at their third stage. Table 1 provides an overview of the main model groups in which the free ports were associated with. Each group relates to a specific form of arbitrage that free ports are mainly used for and usually adds the arbitrage gained by previous models. The first form involved storage and where free ports were able to act as trade buffers and mitigate high taxation regimes. In the second form, free ports assume transformation activities that benefit from the trade arbitrage of sourcing products or parts that cannot be produced locally. The third form exploits the advantage of providing unique trade services, making the free port a generator of added value. The fourth form particularly build arbitrage by having free ports support effective supply chains, particularly as major port facilities within global and regional shipping networks and supporting multi-direction flows. The fifth form sees free ports develop zonal specialization with connected entities related to manufacturing, logistics and services.

There is also a prospective model (Model 6) in which there could be a network of free zones with partnerships on both commercial and physical services, supply chain management and multi-directional flows of goods. Such a free port does not yet fully exist as it would represent a regional or global cluster of infrastructures that reduces the friction of borders to support global supply chains. In this prospective model, free ports could become a network of free trade clusters, in which free ports, through strategic agreements, would be bound in a network belonging to more than one customs entity. The agreement between Barcelona Free Zone and Tanger-Med is indicative of this process but rely mostly on joint promotion, marketing and management without explicitly involving free trade corridors and the physical trade of goods.

Following this modelization, free ports are observed in most of the world's main container ports (Table 2). In fact, out of the 25 largest container ports, only one does not have a free port area (Antwerp).

\section{Discussion and conclusion}

Free ports are based on a form of exceptionalism which has existed since Antiquity. They have seen their role and function evolve to follow political, economic and 
Table 1 Free Port Model Groups

Model Group 1 - Storage Arbitrage

1 Piraeus Model Importing goods that are stored without tax and then re-exported to other cities or taxed as they entered the city in which the free port was part of. Permitted the emergence of the first trade hubs.

Model Group 2 - Transformation Arbitrage

2.1 Delos / Hamburg Expansion of model 1 to include some logistics or light manufacturing services. Goods Model entering the free port could be different than the goods exiting because of some form of transformation is performed.

Model Group 3 - Added Value Arbitrage

3.1 Villefranche Model Included a larger range of services, such as banking, housing and fairs to support commercial activities. Typical of free cities emerging in the Middle Ages.

3.2 Trieste Model

Gateways to custom areas in which goods either enter before being transformed and imported in the domestic area or exit from the domestic custom area through the free port where they are transformed before being exported.

Trieste was a gateway for several continental European countries (some landlocked like Austria).

3.3 Geneva Model Importing goods, storing them and then re-exporting these goods without transformation. Suitable for high value goods that are susceptible to increase in value and subject to a high taxation regime under normal circumstances.

The Geneva free port is used to store high value goods without tax such as art objects, precious metals or wine.

Model Group 4 - Supply Chain Arbitrage

4.1 Hueneme Model Expansion of the Trieste Model in which there is either an entering flow or a separated exiting flow, but without re-exporting flows (goods can however be moved to another free port within the same customs entity). Act as commercial buffers since transformations and supply chain services are provided while goods are inside the free port.

Typical model of American foreign trade zones.

4.2 Barcelona Model Importing goods from foreign trade or from partner free zones either located in the domestic customs area or outside. Customs corridors linking a network of duty free zones. Goods coming from the same customs area are exported and goods coming from external customs areas are imported. Transformation can also take place in the zone.

Barcelona Free Port, servicing free zones in Cataluña and with a customs corridor with Tanger-Med Free Port.

4.3 Kaohsiung Model Goods enter either from the domestic area or from the outside, are then stored and transformed and finally are either imported or re-exported.

Typical of Asian emerging economies and often represented as a free trade zone because it does not allow heavy transformations and other services like in export processing zones.

4.4 Dakar Model Importing and re-exporting goods without transformation. A storage buffer for goods bound for another customs entity. The services provided are directed toward other free zones in landlocked countries.

Dakar free port services landlocked countries such as Mali.

Model Group 5 - Zonal Specialization Arbitrage

5.1 Mauritius Model Similar to model 4.2 except supply chain services are offered in the free port and transformation and IT services offered in a network of free zones in the domestic customs area.

5.2 Dubaï Model_ Similar to model 4.3, but offering a wider range of services beyond logistics and transformation, such as conference centers, marketing, law and consulting firms which are providing managerial services to supply chains.

Hong Kong, as a free port, serviced a similar function since its foundation in the 19th century.

5.3 Tanger-Med Importing, transforming and re-exporting goods with all the supply chain services loModel cated in a network of free zones.

Tanger Region has an automotive production zone, an industrial processing zone and an IT zone, including promotional agreements with the free port of Barcelona.

Model Group 6 (Prospective) - Network of Free Ports 
Table 22012 TEUs port ranking and free zones models

\begin{tabular}{|c|c|c|c|}
\hline $\begin{array}{l}2012 \text { TEUs } \\
\text { Ranking } \\
\end{array}$ & $\begin{array}{l}\text { Major Container } \\
\text { Ports }\end{array}$ & Free Port & $\begin{array}{l}\text { Type of Free } \\
\text { Port }\end{array}$ \\
\hline 1 & Shanghai & Shanghai Waigaoqiao Free Trade Zone & 5.3 \\
\hline 2 & Singapore & $\begin{array}{l}\text { Singapour, Jurong, Sembawang, Pasir Pajang, } \\
\text { Changji FTZ }\end{array}$ & 2.1 \\
\hline 3 & Hong Kong & Hong Kong Free Port & 2.1 \\
\hline \multirow[t]{3}{*}{4} & Shenzhen & Shenzhen Futian Free Trade Zone & 5.1 \\
\hline & Shenzhen & Shenzhen Shatoujiao Free Trade Zone & \\
\hline & Shenzhen & Shenzhen Yantiangang Free Trade Zone & \\
\hline 5 & Busan & Busan Harbor Tariff Free Zone & 4.3 \\
\hline 6 & Ningbo-Zhoushan & Ningbo Free Trade Zone & 5.2 \\
\hline 7 & Guangzhou & Guangzhou Free Trade Zone & 5.2 \\
\hline 8 & Qingdao & Qingdao Free Trade Zone & 5.2 \\
\hline 9 & Dubaï Ports & Jebel Ali Free Zone & 5.2 \\
\hline 10 & Tianjin & Tianjin Port Free Trade Zone & 5.2 \\
\hline 11 & Rotterdam & Schiphol Airport Free Zone & 4.3 \\
\hline 12 & Port Klang & Port Klang Free Zone & 4.3 \\
\hline 13 & Kaohsiung & Kaohsiung Free Trade Zone & 4.3 \\
\hline 14 & Hamburg & Port of Hamburg Free Trade Zone ${ }^{a}$ & 2.1 \\
\hline 15 & Antwerp & None & \\
\hline 16 & Los Angeles & FTZ No. 202 Los Angeles & 4.1 \\
\hline 17 & Dalian & Dalian Free Trade Zone & 5.2 \\
\hline 18 & Tanjung Pelepas & Pelepas Free Zone & 4.3 \\
\hline 19 & Xiamen & Xiamen Xiangyu Free Trade Zone & 5.1 \\
\hline 20 & Tanjung Priok & Tanjung Priok Export Processing Zone & 5.2 \\
\hline 21 & $\begin{array}{l}\text { Bremen/ } \\
\text { Bremerhaven }\end{array}$ & Freihafen I & 2.1 \\
\hline 22 & Long Beach & FTZ No. 50 Long Beach & 4.1 \\
\hline 23 & Laem Chabang & 304 Industrial Park Chachoengsao & 4.1 \\
\hline 24 & $\begin{array}{l}\text { New York/New } \\
\text { Jersey }\end{array}$ & FTZ No. 49 Newark/Elizabeth & 4.1 \\
\hline 25 & Saigon Port & Tan Thuan Export Processing Zone & 5.1 \\
\hline
\end{tabular}

Adapted from AAPA's World Port Ranking 2012

an 2013, Hamburg forfeited its free port status that it held for more than 125 years as part of the Zollverein, and before that since 1189. Advances in EU trade regulations, particularly between member countries, conferred less advantages for this status. Further, the free port was occupying valuable real estate in the port's proximity, which was afterwards redeveloped to new uses

technological developments, particularly as they relate to international trade routes. Because of these changes, some free ports disappeared while others gained and lost their importance with the ebb and flows of global trade. Globalization underlines the enduring fundamental niche that free ports play as international trade gateways, with most countries having a regulatory environment enabling free ports, with some actively promoting them. Their use remains a market strategy for actors seeking a form of arbitrage such as traders, transport and logistics companies and even financial firms. They have been effective tools of transnationalism as the examples of Shenzhen and Dubai underline. Yet, free port status does not guarantee economic development since there are numerous free ports that provided limited economic and trade impetus. The 
insertion of free ports within existing trade networks remains a key factor in their success, but this success is often observed afterwards.

This paper provided a conceptualization of contemporary free ports and underlined three main factors explaining the evolution of free ports, which was concomitant with the evolution of international trade. They include the regulatory context, the function and trade orientation. These three factors helped articulate models explaining the development of free ports in a variety of contexts. In addition, these factors helped understand what drives the transition from one model to another. Based upon this evolution it is possible to infer about a prospective free port model that would involve networks of free trade clusters through strategic agreements. As such, the current trend underlines that trade gateways could further consolidate their role by networking their free zones with other gateways with which they have functional relations. This would obviously require more advanced forms of trade facilitation measures and customs agreements, but networked free ports would support more competitive supply chains, particularly if they enhance the complementarity of the trade relations they support. Therefore, stakeholders have active interests in supporting the emergence of these free port clusters. These decisions are likely going to be made where there is a strong complementarity in the value-added functions, particularly with reverse trade flows.

Several questions remains to be answered. First, under what circumstances are the decisions made to open, to expand as well as to close a free port? For instance, in 2013 Hamburg forfeited its free port status, which it held for centuries. This underlines that the arbitrage that the free port provided was no longer judged to be valuable enough to maintain. Another example being post-Brexit UK striving to create free ports in order to position itself as a major supply chain link between the Commonwealth and the E.U. (Sunak, 2016). This underlines that free ports could even thrive in a global context of potential trade restrictions since their arbitrage function would be even more prevalent. Second, further research is needed to compare the different free ports models and identify macro-economic as well as geographical factors driving the development of a specific model. This could provide analytical and decision-making tools to better understand the dynamics of free ports and how they continue to support global trade and supply chains. It is also unclear how path dependent different free port models are, implying that once a free port has been established, to what extent it can evolve into new forms and new value propositions. Still, it is fairly surprising that in light of ongoing trade liberalization, including the setting of economic blocs, that free ports remain an active and even thriving element of global trade.

\section{Endnotes}

${ }^{1}$ Inward Processing Relief is a method of obtaining relief from Customs duties and VAT charges. The relief applies to goods imported from outside the EU, processed and exported to countries outside the EU after they have undergone manufacturing, processing or repair.

${ }^{2}$ It even maintained between 1980 and 1994 a separate currency called Foreign Exchange Certificates. 


\section{Funding}

Funding information is not applicable, no funding was received.

\section{Authors' contributions}

Authors contributed jointly to the manuscript. All authors read and approved the final manuscript.

\section{Competing interests}

The authors declare that they have no competing interests.

\section{Publisher's Note}

Springer Nature remains neutral with regard to jurisdictional claims in published maps and institutional affiliations.

\section{Author details}

${ }^{1}$ Métis Lab, École de Management de Normandie, Le Havre, France. ${ }^{2}$ Department of Global Studies \& Geography, Hofstra University, Hempstead, New York, USA.

Received: 21 August 2017 Accepted: 12 December 2017

Published online: 28 December 2017

\section{References}

Abbott A (1992) What do cases do? Some notes on activity in sociological analysis. In: Ragin CC, Becker HS (eds) What is a case?: exploring the foundations of social inquiry. University of Cambridge, Cambridge, pp 53-82

Abu-Lughod JL (1991) Before European hegemony: the world system a.D. 1250-1350. Oxford University Press, Oxford

Aftalion A (1901) Les Ports francs en Allemagne et les projets de création de ports francs en France. Société d'économie politique nationale, Paris

Amirahmadi H, Weiping W (1995) Export processing zones in Asia. Asian Survey 35(9):828-849

Arvis JF, Raballand G, Marteau JF (2007) The cost of being landlocked: logistics costs and supply chain reliability. World Bank Publications, Washington

Baissac C (1996) A critique of cost-benefit analysis in the evaluation of export processing zones. Journal of the Flagstaff Institute 2(1):28-38

Barbier JP, Véron JB (1991) Les zones franches industrielles d'exportation: Haïti Maurice Sénégal Tunisie. KARTHALA Editions, Paris

Blanc F (1996) Les zones franches portuaires. Revue juridique Neptunus 2(6):1-7

Bost $F$ (2007) Les zones franches interfaces de la mondialisation. Annales de géographie 6:563-585

Bost F (2010) Atlas mondial des zones franches. La Documentation française, Paris

Bost $F$ (2011) Are economic free zones good for Development? OECD West African Challenges 4:4-20

Congress of the United States Foreign Trade Zone Board (2013) 74th annual report of the foreign- trade zones board to the congress of the United States

Donnadieu G, Karsky M (2002) La systémique: penser et agir dans la complexité. Liaisons, Paris

Durand D, Nuñez E (2002) Pour Une Pédagogie Opérationnelle de L'approche Systémique. ResSystemica, Association française des sciences des systèmes, Paris, France

Easton G (1995) Methodology in industrial networks. In: Moller K, Wilson DT (eds) Business marketing: an interaction and network perspective. Kluwer, Norwell, pp 411-492

Easton G (1998) Case research as a methodology for industrial networks: a realist apologia. In: Naude P, Turnbull P (eds) Network dynamics in international marketing. Pergamon, Oxford, pp 73-87

Eisenhardt K (1989) Building theories from case study research. Academy of Management Review 14:532-550

Farole T (2011) Special economic zones in Africa: comparing performance and learning from global experiences. World Bank Publications, Washington

Fedi L, Lavissière A (2014) Les régimes d'exploitation des ports francs au début du 21ème siècle. Droit Maritime Français 759:766-774

Hasebroek J (1928) Staat Und Handel Im Alten Griechenland. Mohr, Tübingen

Haywood R (2000). Free zones in the modern world. Paper presented at the CFATF meeting Aruba October $18^{\text {th }}$

ILO/UNCTC (1988) Economic and social effects of multinational enterprises in export processing zones. UN Publications, Geneva Swiss

Kugler H (1922) Die Entstehung Der Neuen Freihafenformen. J. Fischer, lena, Germany

Kusago T, Tzannatos Z (1998) Export processing zones: a review in need of update. World Bank Publications, Washington

Lafargue Y (2008) Les zones franches industrielles et logistiques dans la Supply Chain mondiale. Paper presented at the 18th journée CPIM de France Paris

Lavissière A (2014) Les ports francs en Méditerranée et l'exception Marseillaise. Annales de l'Institut Méditerranéen des Transports Maritimes CMCl, Marseille

Lavissière A, Fedi L, Cheaitou A (2014) A modern concept of free ports in the 21st century: a definition towards a supply chain added value. Supply Chain Forum: an International Journal 15(3):22-28

Lavissière A, Mandjak T, Fedi L (2016) The key role of infrastructure in backshoring operations: the case of free-zones. Supply Chain Forum: an International Journal 17(3):143-155

Lombard-Jourdan A (1987) Les Foires de L'abbaye de Saint-Denis; Revue Des Données et Révision Des Opinions Admises. Bibliothèque de l'école des chartes 145(2):273-338

Lu CS, Yang CC (2007) An evaluation of the investment environment in international logistics zones: a Taiwanese Manufacturer's perspective. International Journal of Production Economics 107(1):279-300

Madani D (1999) A review of the role and impact of export processing zones. World Bank Publications, Washington 
Miyagiwa KF (1986) A reconsideration of the welfare economics of a free-trade zone. Journal of International Economics. 21(3-4):337-350

Rhee, Y.W., K. Katterbach and J. White (1990) "Free trade zones in export strategies." industry development division, industry series paper no. 36, World Bank

Rodrigue JP (ed) (2017) The geography of transport systems, 4th edn. Routledge, New York

Rodrigue JP, Notteboom T (2009) The Terminalization of supply chains: reassessing the role of terminals in port/ hinterland logistical relationships. Maritime Policy and Management 36(2):165-183

Roso V, Woxenius J, Lumsden K (2009) The dry port concept: connecting container seaports with the hinterland. Journal of Transport Geography 17(5):338-345

Schrank A (2001) Export processing zones: free Market Islands or bridges to structural transformation? Development Policy Review 19(2):223-242

Schwob T, Lorot P (1987) Les Zones Franches Dans Le Monde. La Documentation française, Paris Sheffi Y (2012) Logistics clusters: delivering value and driving growth. The MIT Press, Cambridge

Slack B (1999) Satellite terminals: a local solution to hub congestion? Journal of Transport Geography. 7(4):241-246

Sunak R (2016) The free ports opportunity: how Brexit could boost trade manufacturing and the north. Center for Policy Studies, Surrey

Susman P, Schneider G (2008) Institutional challenges in the development of the World's first worker-owned free trade zone. Journal of Economic Issues 42(2):489-498

Thoman RS (1956) Free ports and foreign trade zones. Cornell Maritime Pr/Tidewater Pub, Maryland

Tiefenbrun S (2012) Tax free trade zones of the world and in the United States. Edward Elgar Publishing, Cheltenham Trampus F (1999) Free ports of the world. Editrice Università di Trieste, Trieste

Wang J (2013) The economic impact of special economic zones: evidence from Chinese municipalities. Journal of Development Economics 101:133-147

Wilmsmeier G, Monios J, Lambert B (2011) The directional development of intermodal freight corridors in relation to inland terminals. Journal of Transport Geography. 19(6):1379-1386

World Bank (2008) Special economic zones: performance, lessons learned, and implications for zone development. The World Bank, Washington

Yang YC (2009) Key successful assessment criteria for hinterland development on free trade zone: based on fuzzy AHP approach. Transportation Planning Journal 38(2):1-30

Submit your manuscript to a SpringerOpen ${ }^{\circ}$ journal and benefit from:

- Convenient online submission

- Rigorous peer review

- Open access: articles freely available online

- High visibility within the field

- Retaining the copyright to your article 